\title{
MODEL CTL UNTUK MENINGKATKAN HASIL BELAJAR MATEMATIKA KELAS V SDN 104/IX KEDEMANGAN
}

\author{
Jamalia \\ SDN 104/IX Kedemangan Muaro Jambi \\ Email: jamalia747@gmail.com
}

\section{Info Artikel}

\section{Sejarah Artikel:}

Diterima 10 Oktober 2018

Direvisi 28 November 2018

Disetujui 30 November 2018

Keywords:

CTL Model, learning outcomes,

Mathematics

\begin{abstract}
The purpose of this research is to increase learning outcome in MTK subjects in class V. This research is a Classroom Action Research, includes: planning, implementation, and reflection, 29 study subjects consisted of 15 males and 14 females, Data collection techniques used a written assessment on the basic competence of multiplying and dividing various forms of fractions, observations in the form of indicators of teacher and student, the results showed that pre cycle of percentage of student learning outcomes that is $38 \%$, in the first cycle increased by a percentage $72 \%$, teacher activity by $75 \%$, and student activity by $70 \%$ and then in the second cycle is $100 \%$ complete, with the highest 85 , the lowest 75 , and the average 78,97. Based on these results, it can be concluded that CTL model can improve the learning outcomes of Mtk subject of grade V students at elementary school number 104 / IX Kedemangan
\end{abstract}

\begin{abstract}
Abstrak
Penelitian ini bertujuan untuk meningkatkan hasil belajar siswa pada pelajaran MTK kelas $\mathrm{V}$, jenis penelitian yaitu penelitian tindakan kelas (PTK), meliputi empat tahap yaitu perencanaan, pelaksanaan, observasi dan refleksi, subyek penelitian berjumlah 29 siswa terdiri dari 15 laki-laki dan 14 perempuan, Teknik pengumpulan data menggunakan penilaian tertulis untuk memperoleh data hasil belajar mata pelajaran MTK pada kompetensi dasar mengalikan dan membagi berbagai bentuk pecahan, observasi berbentuk indikator keberhasilan guru dan indikator keberhasilan siswa. Hasil penelitian menunjukkan bahwa persentase hasil belajar siswa pada pra siklus sebesar $38 \%$, meningkat pada siklus I sebesar $72 \%$, aktivitas guru sebesar $75 \%$, dan aktivitas siswa sebesar $70 \%$, selanjutnya siklus II dinyatakan $100 \%$ tuntas dengan nilai tertinggi 85 , terendah 75 , dan rata-rata 78,97. Berdasarkan hasil temuan penelitian dapat disimpulkan bahwa model pembelajaran Contextual Teaching and Learning dapat meningkatkan hasil belajar siswa kelas V pada mata pelajaran MTK SDN 104/IX Kedemangan.
\end{abstract}

(C) 2018 Universitas Muria Kudus 
Jamalia.

MODEL CTL UNTUK MENINGKATKAN HASIL BELAJAR MATEMATIKA ...

REFLEKSI EDUKATIKA: Jurnal Ilmiah Kependidikan, Nomor 9, Volume 1, Desember 2018, hlm. 82-89

\section{PENDAHULUAN}

Matematika merupakan salah satu mata pelajaran yang penting bagi peserta didik yang dianggap sebagai pondasi mendobrak cakrawala daya pikir khususnya di bidang teknologi informasi dan komunikasi yang dewasa ini menjadi trending topik terkini dengan pemunculan berbagai bentuk-bentuk keajaiban, munculnya keajaiban tersebut sulit memisahkan diri dari kemahiran seseorang dalam menggunakan ilmu yang dimuat dalam mata pelajaran matematika yaitu penguasaan bidang teori bilangan, aljabar, dan kemampuan analisis yang handal. Dalam merekonstruksi analisis perkembangan bidang teknologi dan komunikasi dewasa ini akan selalu ada sejumlah rumusrumus yang setia mendampingi.

Muatan matematika tidak hanya berbicara mengenai jurus jitu mendobrak cakrawala sebagaimana di singgung sebelumnya, namun juga meluas dalam kehidupan masyarakat, peserta didik yang mendapatkan pelajaran matematika sejak dini mulai dari bangku sekolah dasar hingga ke jenjang lebih atas, memberikan nilai tambah bagaimana peserta didik di setiap tahap perkembangannya memiliki kemampuan berpikir logis, analitis, kritis, kreatif dan kemampuan bekerjasama, dengan demikian memberikan kontribusi besar terhadap cara peserta didik memperoleh sejumlah informasi yang juga meliputi sejumlah isu-isu manakala berhadapan dengan permasalahan, baik dalam lingkungan keluarga, lingkungan sekolah dan lingkungan masyarakat yang lebih luas, memiliki kemampuan mengelolah isu-isu dan atau sumber-sumber yang di terima dengan logis, analitis, kritis, dan kreatif, dan terus berjalan hingga pada kemampuan peserta didik dalam memanfaatkan isu-isu atau sumber-sumber yang diterima untuk bertahan hidup pada keadaan yang kian berubah.

Namun demikian, kendatipun bidang ilmu matematika diyakini sebagai pondasi pengembangan khususnya teknologi informasi dan komunikasi sebagaimana disinggung sebelumnya di samping menciptakan sikap logis, kritis, analitis, kreatif dan kemampuan bekerjasama hingga meluas sebagai anggota mayarakat, namun pada kenyataannya tidak sedikit hasil riset muthahir menunjukkan bahwa masih tingginya sikap pesimistik peserta didik terhadap penguasaan bidang ilmu matematika, mata pelajaran matematika terpaksa menjadi salah satu mata pelajaran yang harus berada di samping hingga berujung pada rendahnya hasil belajar siswa.

Kekhawatiran tersebut sangat dekat dengan dasar dilakukannya penelitian ini, terungkap melalui sesi wawancara bersama beberapa partisipan dalam hal ini siswa kelas V, dimana siswa menyatakan bahwa pelajaran MTK adalah pelajaran yang paling sulit, pelajaran yang memerlukan konsentrasi tinggi, pelajaran yang terlalu tegang, terlalu serius, hingga pengakuan bahwa pelajaran MTK merupakan pelajaran yang cepat membawa kebosanan. Berdasarkan hasil wawancara tersebut peneliti memiliki dugaan yang kuat bahwa faktor tersebutlah yang menjadi faktor utama rendahnya hasil belajar siswa yang berujung tidak terpenuhinya KKM MTK sebesar 73 sebagaimana yang ditetapkan. Selaras dengan itu Leonard \& Supardi (Achmad Setyawan dan Leonard, 2017: 737) menyatakan bahwa disamping faktor eksternal, sikap siswa dalam hal ini bagaimana siswa mempersepsikan bahwa pelajaran MTK adalah pelajaran yang sulit yang berujung pada kecemasan siswa adalah faktor yang sangat memengaruhi hasil belajar siswa.

Setelah menumpuh kajian pustakaan dengan fokus menemukan model pembelajaran yang dapat merespon kesenjangan yang ada, ditemukan begitu banyak alternatif solusi yang ditawarkan, namun masing-masing model memiliki kelebihan dan kekurangan disamping menuntut guru untuk dapat menyesuaikan kebutuhan peserta didik dan kompetensi yang ingin dicapai, berangkat dari simpulan tersebut peneliti mengawalinya dengan pengklasifikasian tahap-tahap perkembangan anak yang menjadi subjek dalam penelitian ini, mengingat siswa kelas V rata-rata berumur 11 tahun Piaget (Kusdwiratri, S, 2009: 20 - 21) menyatakan pada tahap perkembangan kognisi umur 7 - 11 tahun disebut tahap concrete operational dimana anak memiliki kemampuan konservasi terhadap dirinya yang merupakan indikasi penalaran ilmiah, baik mengenai cairan, panjang, jumlah, bentuk, dan sebagainya. Selaras dengan itu Sullivan (Hamdi, M 2016: 95) menyatakan bahwa pada umur $8-11$ tahun anak belajar bekerja sama dan bersaing dengan yang lain, pada masa ini anak-anak mulai membandingkan segala sesuatu yang diterima dirumahnya dengan yang dia temui di luar.

Bertolak dari tahap perkembangan anak sebagaimana dikemukakan di atas, dengan memperhatikan karakteristik anak, gaya belajar, prinsip-prinsip pelajaran matematika kelas $\mathrm{V}$ dan kesiapan belajar siswa peneliti menemukan 
Jamalia.

MODEL CTL UNTUK MENINGKATKAN HASIL BELAJAR MATEMATIKA ...

REFLEKSI EDUKATIKA: Jurnal Ilmiah Kependidikan, Nomor 9, Volume 1, Desember 2018, hlm. 82-89

bahwa model pembelajaran Contextual Teaching and Learning (CTL) merupakan model pembelajaran yang tepat dan sesuai untuk menjawab kesenjangan yang ada, keyakinan tersebut diperkuat oleh hasil penelitian Acmad Setyawan dan Leonard (2017) penelitian dengan fokus pengaruh model pembelajaran CTL terhadap hasil belajar MTK siswa, hasil penelitian menunjukkan bahwa model pembelajaran CTL berpengaruh terhadap hasil belajar MTK siswa. Selanjutnya Tutut Rahmawati (2018) penelitian dengan fokus penerapan model CTL untuk meningkatkan hasil belajar siswa dengan metode studi kepustakaan, hasil penelitian menunjukkan bahwa model CTL direkomendasikan untuk dapat diterapkan pada mata pelajaran MTK. Lebih jauh Susanto, A, (20016: 205) menyatakan bahwa pendekatan pelajaran matematika yang sangat populer saat ini yaitu matematika realistis dengan esensi aktivitas manusia (human activity) dalam prosesnya siswa diberikan kesempatan untuk menemukan (reinvent) dengan penghubungan terhadap konteks kehidupan sehari hari siswa, hal yang senada juga dikemukan oleh Aqib, Z, (2017: 6) menyatakan bahwa: model pembelajran CTL dapat diterapkan pada kurikulum apa saja, bidang studi apa saja, dan kelas yang bagaimanapun keadaannya.

Melalui model pembelajaran CTL yang dapat menggiring peserta didik mengaitkan antara materi yang diajarkan dengan situasi dunia nyata memberikan nilai tambah bagi pengembangan kognitif siswa dengan probabilistik menciptakan stimulus akan pengembangan psikomotorik peserta didik yang diyakini dapat meningkatkan hasil ouput dari sebuah kompetensi yang dicapai dalam pelajaran. Selaras dengan itu Taniredja, T, dkk, 2017: 52) yaitu bagaimana seorang guru dipacu untuk mendorong peserta didik pengaitkan pengetahuan yang dimiliki terhadap materi pelajaran dengan keadaan dan atau situasi dunia nyata siswa yang dijalani dalam kehidupannya sehari hari sebagai siswa, anggota keluarga, dan anggota masyarakat.

Berdasarkan pendapat di atas mengindikasikan tututan tersendiri bagi guru untuk memahami lebih dekat secara faktual terhadap keadaan dunia nyata peserta didik, dengan simpulan yang tepat terhadap sebuah persepsi akan keadaan dunia nyata siswa, cenderung memberikan peluang tersendiri bagi siswa untuk dapat bereksplorasi dengan pengetahuan, pemikiran, opini, dan rasa kaingintahuan terhadap sesuatu hal yang berhubungan dengan keadaan siswa sendiri dalam menjalani kegiatan rutinitas sehari hari.

Sebagaimana dimaklumi berbagai model pembelajaran memiliki juknis dalam melaksanakan langkah demi langkahnya dan dengan sendirinya mendeskripsikan eksistensi dari model pembelajaran itu sendiri, sama halnya dengan metode pembelajaran CTLyang memiliki kaarakteristik sebagai berikut: (1) adanya kerja sama; (2) adanya saling menunjang; (3) terciptanya rasa senang dan tidak membosankan; (4) dapat belajar dengan keinginan yang kuat; (5) pembelajaran terintegrasi; (6) menggunakan berbagai sumber; (7) siswa aktif; (8) sharing dengan teman; (9) siswa kritis guru kreatif; (10) tempat-tempat yang dipenuhi dengan pengalaman belajar baik berupa peta-peta, gambar-gambar, artikel, humor dan sebagainya; (11) laporan kepada orang tua bukan hanya rapor tetapi hasil karya siswa, laporan hasil praktikum, karangan siswa dan laporan kerja lainnya (Aqib, Z, 2017: 8).

Selanjutnya tinjauan tentang belajar sebagaimana Sardiman, (2014: 22) menyatakan bahwa belajar merupakan proses interaksi antara diri personal dengan lingkungan yang dapat berupa fakta, sebuah konsep, teori atau perwujudan pribadi seseorang. Sejalan dengan itu Nasution, (2013: 3) menyatakan bahwa pencapaian proses belajar seyogianya berangkat dari sebuah stuktur yang terorganisir dengan demikian apa yang dipelajari dapat memberikan nilai guna di kemudian hari hingga akhirnya membantu membentuk pribadi yang utuh untuk terus belajar dengan cara yang tepat, mudah dan kontinuitas. Selanjutnya sebuah proses pencapaian suatu tujuan senantiasa selalu diikuti keberhasilan yang dicapai, dalam hal ini Djaali, (2015:101) menyatakan faktor yang memengaruhi keberhasilan peserta didik meliputi motivasi, sikap, minat, kebiasaan belajar dan konsep diri.

Sedangkan tinjauan tentang hasil belajar Sudjana (2011: 43) menyatakan bahwa hasil belajar merupakan output atau keluaran hasil setelah peserta didik menempuh pengalaman belajar yang ditandai adanya perubahan tingkah laku (behavioral change), bentuk kongkrit dari sebuah pengalaman belajar dimaksud dapat berupa terbentuknya kemampuan mengetahui dari semula tidak mengetahui, keadaan mengerti dari semula tidak mengerti dan atau dari semula tidak memahami menjadi paham. Senada dengan itu Sardiman, (2014: 26 - 28) mengemukakan 
Jamalia.

MODEL CTL UNTUK MENINGKATKAN HASIL BELAJAR MATEMATIKA ...

REFLEKSI EDUKATIKA: Jurnal Ilmiah Kependidikan, Nomor 9, Volume 1, Desember 2018, hlm. 82-89

hasil dari sebuah belajar ditandai dengan tercapainya tujuan yang dituangkan dalam pembelajaran itu sendiri yang berupa mendapatkan pengetahuan, konsep dan keterampilan dan pembentukan sikap. Lebih lanjut Susanto, A (2016: 5) menyatakan hasil belajar yaitu terjadinya sebuah perubahan pada aspek kognitif, afektif dan psikomotorik siswa yang merupakan hasil dari kegiatan belajar. Berikutnya ukuran keefektifan hasil belajar dalam hal ini Sudjana, (2011: 54) menyatakan bahwa pembelajaran yang berhasil ditunjukkan oleh tercapainya hasil belajar yang optimal.

Bertolak dari kesenjangan sebagaimana fenomena yang terjadi di lapangan yang dikemukakan pada latar belakang di atas, setelah melalui tahapan kajian literatur terhadap model yang tepat guna dan tepat sasaran sebagai respon kesenjangan yang ada, temuan hasil beberapa penelitian yang relevan, dengan memperhatikan keselarasan model dengan kompetensi yang ingin dicapai pada pelajaran MTK, karakteristik peserta didik, gaya belajar, kesiapan belajar, dan kesesuaian dengan sifat bahan ajar maka, peneliti tertarik mengadakan penelitian dengan jenis penelitian tindakan kelas (Classroom Action Research) dengan mengangkat judul: MODEL CTL UNTUK MENINGKATKAN HASIL BELAJAR PELAJARAN MATEMATIKA KELAS V SDN 104/IX KEDEMANGAN.

Adapun rumusan masalah dalam penelitian ini yaitu bagaimana model CTL untuk meningkatkan hasil belajar siswa pada mata pelajaran mtk kelas V SDN 104/IX kedemangan? Tujuan penelitian yaitu untuk mengetahui model CTL dalam meningkatkan hasil belajar siswa pada mata pelajaran mtk kelas V SDN 104/IX kedemangan. Manfaat penelitian yaitu bagi guru sebagai referensi bahwa model CTL dapat meningkatkan hasil belajar mata pelajaran mtk, disamping itu guru dapat melakukan pengujian lanjutan keefektifan model CTL melalui penelitian lanjutan untuk diterapkan pada mata pelajaran lainnya dengan memperhatikan esensi dan karakteristik model CTL dalam pembelajaran, bagi siswa dapat membuka ruang untuk menjadi lebih dewasa dalam berpikir kritis, idealis dalam menemukan pemecahan masalah yang diperluas dalam menjalani aktivitas sehari hari sebagai siswa, anggota keluarga dan anggota masyarakat, bagi sekolah dapat dijadikan sarana memperbaiki mutu proses dan mutu hasil pembelajaran yang kemudian berdampak pada kualitas dan mutu sekolah secara keseluruhan.

\section{METODE PENELITIAN}

Jenis penelitian ini yaitu penelitian tindakan kelas (Classroom Action Research), Desain yang digunakan dalam penelitian ini adalah menggunakan model Kemmis \& mc taggart yang terdiri dari perencanaan, tindakan, observasi dan refleksi (Arikunto, S. 2006: 93). Lokasi penelitian yaitu SDN No 104/IX Kedemangan, waktu penelitian yaitu semester dua tahun ajaran 2017/2018, subjek penelitian yaitu siswa kelas V yang berjumlah 29 siswa terdiri dari 15 laki-laki dan 14 perempuan. Teknik pengumpulan data berupa observasi kinerja guru dalam bentuk indikator keberhasilan guru, dan observasi aktivitas belajar siswa dalam bentuk indikator keberhasilan siswa dan hasil belajar Mtk siswa, sedangkan Teknik analisis data diambil dari hasil lembar observasi aktivitas guru, lembar observasi aktivitas siswa dan soal tes hasil belajar.

Adapun rumus yang digunakan untuk mengukur ketuntasan individu yaitu:

$\mathrm{PK}=\frac{s}{s m} \times 100$

Keterangan:

PK : Persentase ketuntasan individu

SP : : Skor yang diperoleh siswa

SM : Skor maksimal

Rumus yang digunakan untuk menentukan ketuntasan klasikal yaitu: $\mathrm{KK}=\frac{N}{\pi t} x 100$

Keterangan:

KK : Ketuntasan klasikal

$\mathrm{N} \quad$ : Jumlah siswa yang tuntas

ST : Jumlah siswa seluruhnya

Sedangkan analisis keberhasilan aktivitas guru dan aktivitas siswa yang berbentuk lembar observasi dianalisis menggunakan rumus:

Presentase rata-rata (NR)

$=\frac{\text { Jumlah shor }}{\text { Tumlah Mahsimal }} \times 100 \%$

Penelitian dikatakan berhasil apabila hasil belajar siswa secara individual ataupun secara klasikal memenuhi KKM sebesar 73.

\section{HASIL PENELITIAN DAN PEMBAHASAN}

Sebelum melakukan langkah tindakan siklus pertama dengan mempedomani langkahlangkah berupa skenario tindakan pada tahap rencana tindakan, diadakan tes awal untuk 
mengetahui kondisi awal hasil belajar peserta didik. Hasil belajar siswa pada kondisi pra siklus dapat dilihat pada Tabel 1.

Tabel 1. Ketuntasan Belajar Peserta Didik pada pra Siklus

\begin{tabular}{|c|c|}
\hline Uraian & Pra Siklus \\
\hline Nilai Terendah & 45 \\
Tertinggi & 75 \\
Rata-rata Skor & 63,41 \\
Ketuntasan Belajar (\%) & $38 \%$ \\
\hline
\end{tabular}

Berdasarkan Tabel 1 terlihat ketuntasan belajar siswa pada pra siklus hanya menunjukkan presentase sebesar $38 \%$ dengan rata-rata skor sebesar 63,41 , dengan nilai tertinggi 75 dan nilai terendah 45 , pencapain tersebut memberikan umpan balik bagi peneliti yang juga merupakan guru kelas $\mathrm{V}$ untuk melakukan perbaikan pembelajaran guna menentaskan ketuntasan belajar siswa sehingga peserta didik secara individu dan klasikal dapat mencapai KKM sebesar 73 .

\section{Siklus I}

\section{Tahap Perencanaan}

Adapun langkah-langkah yang dilakukan dalam perencanaan tindakan yaitu menyiapkan skenario atau langkah-langkah pembelajaran dengan melibatkan model CTL yang dimuat ke dalam Rencana Pelaksanaan Pembelajaran (RPP); Berkoordinasi bersama observer, dalam hal ini satu orang pengawas pembina, kepala sekolah dan satu orang guru senior; Menyiapkan alat pengumpul data berupa lembar observasi aktivitas guru dan aktivitas siswa; dan soal tes; Lembar soal tes penilaian hasil belajar siswa berkaitan dengan materi mengalikan dan membagi berbagai bentuk pecahan.

Sebelum memasuki langkah tindakan, peneliti memeriksa kembali segala sesuatu yang dipersiapkan di atas sudah terpenuhi, manakala pada tahapan ini peneliti menemukan suatu kendala maka, peneliti melakukan pembenahan/ pencarian solusi atau alternatif lain sehingga segala keperluan yang dibutuhkan terkait rencana tindakan benar-benar terpenuhi.

\section{Tahap Pelaksanaan}

Pada tahap pelaksanaan yang merupakan langkah lanjutan dari tahapan perencanaan, pada prosesnya peneliti melakukan tindakan nyata yang melibatkan model pembelajaran CTL yang dimuat ke dalam RPP. Pada tahap pelaksanaan juga dilakukan observasi aktivitas guru dan observasi aktivitas siswa yang mengacu pada kegiatan belajaran pada masing-masing indikator lembar observasi yang telah disusun. Diakhir pelaksanaan tindakan diadakan tes untuk mengetahui hasil dan ketuntasan belajar siswa.

\section{Tahap Pengamatan/ Observasi}

Tahap ini dilakukan pada proses pembelajaran atau pada tahap pelaksanaan tindakan. Observasi diarahkan pada poin-poin yang telah ditetapkan dalam indikator keberhasilan guru dan indikator keberhasilan siswa, yang dibantu oleh satu orang pengawas pembina, kepala sekolah, dan satu orang guru senior sebagai observer. Adapun Indikator keberhasilan guru meliputi: (1) Penampilan guru di depan kelas; (2) Menyampaikan materi pelajaran yang dikaitkan dengan keseharian siswa; (3) Cara menggunakan alat dan media pelajaran; (4) Cara pengelolaan kelas; (5) Cara merespon pertanyaan dan pendapat peserta didik; (6) Memberi pujian atas keberhasilan peserta didik; (7) Interaksi dengan peserta didik; (8) Memotivasi peserta didik; (9) Memberikan bimbingan individu/ kelompok; dan (10) Pengelolaan waktu. Sedangkan indikator keberhasilan siswa meliputi: (1) Senang dengan mata pelajaran yang diajarkan; (2) Tertarik dengan materi pelajaran; (3) Aktif mendengarkan penjelasan guru saat KBM; (4) Tertarik dengan model pembelajaran CTL; (5) Dapat menerima pelajaran yang diajarkan; (6) Aktif menjawab pertanyaan; (7) Semangat dalam KBM; (8) Senang mengerjakan tugas; (9) Dapat memecahkan masalah yang berkaitan dengan tugas; (10) Dapat mengerjakan soal tes. Adapun hasil observasi aktivitas guru pada siklus I dapat dilihat pada Tabel 2

\section{Tabel 2 Hasil Observasi Aktivitas Guru} Siklus I

\begin{tabular}{|lc|}
\hline \multicolumn{1}{|c|}{ Aktivitas Guru } & Skor \\
\hline Penampilan guru di depan kelas & 3 \\
Cara menyampaikan materi pelajaran & 4 \\
Cara menggunakan alat dan media pelajaran & 3 \\
Cara pengelolaan kelas & 3 \\
Cara merespon pertanyaan dan pendapat & 3 \\
peserta didik & \\
Memberi pujian atas keberhasilan peserta & 3 \\
didik & 2 \\
Interaksi dengan peserta didik & 4 \\
Memotivasi peserta didik & 3 \\
Memberikan bimbingan individu/ kelompok & 2 \\
Pengelolaan waktu & 30 \\
Total skor yang diperoleh & 40 \\
Skor Maksimum Kompetensi =banyaknya & 40 \\
indikator dikalikan dengan skor tertinggi & \\
\hline
\end{tabular}


Jamalia.

MODEL CTL UNTUK MENINGKATKAN HASIL BELAJAR MATEMATIKA ...

REFLEKSI EDUKATIKA: Jurnal Ilmiah Kependidikan, Nomor 9, Volume 1, Desember 2018, hlm. 82-89

\begin{tabular}{|lc|}
\hline \multicolumn{1}{|c|}{ Aktivitas Guru } & Skor \\
\hline $\begin{array}{l}\text { Persentase skor kompetensi = total skor yang } \\
\text { diperoleh dibagi dengan Skor Maksimum }\end{array}$ & $\mathbf{7 5 \%}$ \\
Kompetensi dikalikan $100 \%$ & \\
\hline
\end{tabular}

Berdasarkan Tabel 2 di atas persentase keberhasilan guru pada siklus I menunjukkan pada persentase sebesar $75 \%$ dengan perolehan skor sebesar 30 dari skor maksimal 40.

Sedangkan hasil observasi aktivitas siswa pada siklus I dapat dilihat pada Tabel 3

\section{Tabel 3 Hasil Observasi Aktivitas Siswa} Siklus I

\begin{tabular}{|c|c|}
\hline Aktivitas Peserta Didik & Skor \\
\hline $\begin{array}{l}\text { Senang dengan mata pelajaran yang } \\
\text { diajarkan }\end{array}$ & 3 \\
\hline Tertarik dengan materi pelajaran & 3 \\
\hline $\begin{array}{l}\text { Aktif mendengarkan penjelasan guru saat } \\
\text { KBM }\end{array}$ & 3 \\
\hline Tertarik dengan model pembelajaran CTL & 3 \\
\hline Dapat menerima pelajaran yang diajarkan & 3 \\
\hline Aktif menjawab pertanyaan & 3 \\
\hline Semangat dalam KBM & 3 \\
\hline Senang mengerjakan tugas & 2 \\
\hline $\begin{array}{l}\text { Dapat memecahkan masalah yang berkaitan } \\
\text { dengan tugas }\end{array}$ & 2 \\
\hline Dapat mengerjakan soal tes & 3 \\
\hline Total skor yang diperoleh & 28 \\
\hline $\begin{array}{l}\text { Skor Maksimum Kompetensi = banyaknya } \\
\text { indikator dikalikan dengan skor tertinggi }\end{array}$ & 40 \\
\hline $\begin{array}{l}\text { Persentase skor kompetensi }=\text { total skor } \\
\text { yang diperoleh dibagi dengan Skor } \\
\text { Maksimum Kompetensi dikalikan } 100 \%\end{array}$ & $70 \%$ \\
\hline
\end{tabular}

Berdasarkan Tabel 3 di atas dapat dilihat bahwa keberhasilan aktivitas siswa pada siklus I menunjukkan persentase sebesar 70\% dengan total skor 28 dari skor maksimum 40

Selanjutnya hasil belajar siswa pada siklus I dapat dilihat pada Tabel 4

Tabel 4 Hasil Belajar Siswa Siklus I

\begin{tabular}{|c|c|c|c|c|}
\hline \multirow[b]{2}{*}{ Uraian } & \multicolumn{3}{|c|}{ Hasil Belajar } & \multirow[b]{2}{*}{$\begin{array}{l}\text { Ketuntasan } \\
\text { Belajar (\%) }\end{array}$} \\
\hline & $\begin{array}{c}\text { Nilai } \\
\text { Terendah }\end{array}$ & $\begin{array}{c}\text { Nilai } \\
\text { Tertinggi }\end{array}$ & $\begin{array}{l}\text { Rata2 } \\
\text { skor }\end{array}$ & \\
\hline Pra Siklus & 45 & 75 & 63,41 & $38 \%$ \\
\hline Siklus I & 65 & 80 & 73,86 & $72 \%$ \\
\hline
\end{tabular}

Berdasarkan Tabel 4 di atas terlihat adanya peningkatan yang signifikan terhadap hasil belajar siswa setelah menggunakan model pembelajaran CTL, ketuntasan belajar yang semula $38 \%$ meningkat menjadi $72 \%$, rata-rata skor yang semula 63,41 meningkat menjadi 73,86 , sama halnya dengan nilai tertinggi yang semula 75 meningkat menjadi 80, dan nilai terendah yang semula 45 meningkat menjadi 65 , pencapaian hasil belajar siswa yang memenuhi ketuntasan belajar secara klasikal berdasarkan rata-rata skor tampak sudah memenuhi kriteria ketuntasan namun mengingat sekolah menetapkan KKM dengan kriteria tuntas secara individual dan hasil pada siklus I menunjukkan masih terdapat $22 \%$ yang belum tuntas dengan kata lain terdapat delapan siswa yang belum mencapai KKM 73, oleh karena itu penelitian dilanjutkan pada siklus II.

\section{Tahap Evaluasi dan Refleksi}

Pada tahapan ini, peneliti dan observer membuat pertemuan untuk membahas hasil pembelajaran. Dalam hal ini hasil temuan menentukan perlu dan tidaknya melaksanakan siklus berikutnya. Dengan kata lain apabila dalam siklus I peneliti belum berhasil atau masih banyak peserta didik yang belum mencapai KKM 73, maka penelitian dilanjutkan pada siklus II dan seterusnya, penelitian dapat dihentikan manakala keseluruhan siswa sudah mencapai ketuntasan sebagaimana kriteria 100\% tutas secara individual.

Berdasarkan pelaksanaan tindakan siklus I diperoleh hasil refleksi sebagai berikut: (1) penyampaian materi yang dikaitkan dengan aktivitas sehari-hari siswa dinilai masih perlu penguatan; (2) cara merespon pertanyaan dan pendapat peserta didik dianggap masih perlu ditingkatkan; (3) interaksi dengan peserta didik perlu ditingkatkan sebagai upaya memberikan penguatan, penjelasan lanjutan disaat peserta didik membutuhkan; (4) pengelolaan waktu dianggap perlu diperbaiki sehingga tidak mengambil waktu istirahat peserta didik.

\section{Siklus II}

Setelah mendapatkan sejumlah temuan dari tahapan refleksi pada siklus I, selanjutnya kegiatan berlanjut pada siklus II dengan menempuh tahap perencanaan, pelaksanaan dan evaluasi dan refleksi sebagaimana pada siklus I, kegiatan siklus II memperhatikan hasil temuan dan perbaikan yang disimpulkan pada tahap refleksi siklus I. adapun hasil observasi aktivitas guru siklus II dapat dilihat pada Tabel 5

Tabel 5 Hasil Observasi Aktivitas Guru Siklus

II

\begin{tabular}{|lc|}
\hline \multicolumn{1}{|c}{ Aktivitas Guru } & Skor \\
\hline Penampilan guru di depan kelas & 4 \\
Cara menyampaikan materi pelajaran & 4 \\
Cara menggunakan alat dan media pelajaran & 4 \\
Cara pengelolaan kelas & 4 \\
\hline
\end{tabular}


MODEL CTL UNTUK MENINGKATKAN HASIL BELAJAR MATEMATIKA ...

REFLEKSI EDUKATIKA: Jurnal Ilmiah Kependidikan, Nomor 9, Volume 1, Desember 2018, hlm. 82-89

\begin{tabular}{|lc|}
\hline \multicolumn{1}{|c|}{ Aktivitas Guru } & Skor \\
\hline $\begin{array}{l}\text { Cara merespon pertanyaan dan pendapat } \\
\text { peserta didik }\end{array}$ & 4 \\
Memberi pujian atas keberhasilan peserta & 4 \\
didik & 4 \\
Interaksi dengan peserta didik & 4 \\
Memotivasi peserta didik & 4 \\
Memberikan bimbingan individu/ kelompok & 4 \\
Pengelolaan waktu & 40 \\
Total skor yang diperoleh & 40 \\
Skor Maksimum Kompetensi =banyaknya & \\
indikator dikalikan dengan skor tertinggi & \\
Persentase skor kompetensi = total skor & \\
yang diperoleh dibagi dengan Skor & $\mathbf{1 0 0 \%}$ \\
Maksimum Kompetensi dikalikan 100\% & \\
\hline
\end{tabular}

Berdasarkan Tabel 5 di atas persentase keberhasilan guru pada siklus II menunjukkan pada persentase sebesar $100 \%$ dengan perolehan skor sebesar 40 dari skor maksimal 40. Hasil tersebut mengandung arti aktivitas guru sudah mencapai keberhasilan dalam melakukan proses pembelajaran.

Sedangkan hasil observasi aktivitas siswa pada siklus II dapat dilihat pada Tabel 6

\section{Tabel 6 Hasil Observasi Aktivitas Siswa} Siklus II

\begin{tabular}{|c|c|}
\hline Aktivitas Peserta Didik & Skor \\
\hline $\begin{array}{l}\text { Senang dengan mata pelajaran yang } \\
\text { diajarkan }\end{array}$ & 4 \\
\hline Tertarik dengan materi pelajaran & 4 \\
\hline $\begin{array}{l}\text { Aktif mendengarkan penjelasan guru saat } \\
\text { KBM }\end{array}$ & 4 \\
\hline Tertarik dengan model pembelajaran CTL & 4 \\
\hline Dapat menerima pelajaran yang diajarkan & 4 \\
\hline Aktif menjawab pertanyaan & 4 \\
\hline Semangat dalam KBM & 4 \\
\hline Senang mengerjakan tugas & 4 \\
\hline $\begin{array}{l}\text { Dapat memecahkan masalah yang berkaitan } \\
\text { dengan tugas }\end{array}$ & 4 \\
\hline Dapat mengerjakan soal tes & 4 \\
\hline Total skor yang diperoleh & 40 \\
\hline $\begin{array}{l}\text { Skor Maksimum Kompetensi =banyaknya } \\
\text { indikator dikalikan dengan skor tertinggi }\end{array}$ & 40 \\
\hline $\begin{array}{l}\text { Persentase skor kompetensi }=\text { total skor } \\
\text { yang diperoleh dibagi dengan Skor } \\
\text { Maksimum Kompetensi dikalikan } 100 \%\end{array}$ & $100 \%$ \\
\hline
\end{tabular}

Berdasarkan Tabel 6 di atas dapat dilihat bahwa keberhasilan aktivitas siswa pada siklus II menunjukkan presentase sebesat 100\% dengan total skor 40 dari skor maksimum 40. Pencapaian aktivitas tersebut mengindikasikan bahwa secara keseluruhan aktivitas peserta didik sudah mencapai keberhasilan dalam belajar

Selanjutnya hasil belajar siswa pada siklus II dapat dilihat pada Tabel 7.
Tabel 7 Hasil Belajar Siswa Siklus II

\begin{tabular}{|c|c|c|c|c|}
\hline \multirow{3}{*}{ Uraian } & \multicolumn{3}{|c|}{ Hasil Belajar } & Ketuntasan \\
\cline { 2 - 4 } & $\begin{array}{c}\text { Nilai } \\
\text { Terendah }\end{array}$ & $\begin{array}{c}\text { Nilai } \\
\text { Tertinggi }\end{array}$ & $\begin{array}{c}\text { Rata2 } \\
\text { skor }\end{array}$ & $\begin{array}{c}\text { Belajar (\%) } \\
\text { Siklus I }\end{array}$ \\
\hline Siklus II & 75 & 80 & 73,86 & $72 \%$ \\
Sinn & 85 & 78,97 & $100 \%$ \\
\hline
\end{tabular}

Berdasarkan Tabel $7 \mathrm{di}$ atas terlihat adanya peningkatan yang signifikan terhadap hasil belajar siswa dari siklus I ke siklus II, ketuntasan belajar pada siklus I sebesar 72\% meningkat pada siklus II menjadi $100 \%$, rata-rata skor siklus I sebesar 73,86 meningkat pada siklus II menjadi 78,97, nilai tertinggi siklus I sebesar 85 meningkat pada siklus II menjadi 85 , dan nilai terendah siklus I sebesar 65 meningkat pada siklus II menjadi 75, pencapaian hasil belajar siswa yang memenuhi ketuntasan belajar secara klasikal berdasarkan rata-rata skor tampak sudah memenuhi kriteria ketuntasan yang ditunjukkan perolehan persentase $100 \%$ yang mengandung arti ketuntasan secara individual sudah dapat mencapai KKM sebesar 73. Dengan demikian penelitian dapat diakhiri pada siklus II.

Hasil temuan penelitian ini membuktikan bahwa model pembelajaran CTL dapat meningkatkan hasil belajar siswa dengan memperhatikan esensi dan karakteristik model CTL yaitu bagaimana materi pelajaran dikaitkan dengan aktivitas keseharian peserta didik dalam dunia nyata sebagai siswa, anggota keluarga, dan anggota masyarakat, selaras dengan itu Aqib, Z, (2017: 2) menyatakan bahwa dengan penggunaan model CTL guru lebih banyak berurusan dengan strategi daripada materi informasi sehingga memungkinkan peserta didik menemukan sendiri karena dekat dengan aktivitasnya sehari hari. Sejalan dengan itu Taniredja, T, dkk, 2017:53) menyatakan bahwa model pembelajaran CTL dapat berjalan produktif dan bermakna karena mengaktifkan lima elemen dalam praktik pembelajaran yaitu (1) pengaktifan pengetahuan yang sudah ada (activating knowledge); (2) pemerolehan pengetahuan baru (acquiring knowledge) yaitu dengan mempelajari secara keseluruhan baru kemudian melakukan pemerincian; (3) menyusun konsep sementara dengan sharing bersama siswa lainnya untuk mendapat tanggapan dan dengan tanggapan diteruskan dengan revisi dan pengembangan; (4) mempraktikkan pengetahuan dan pengalaman; dan (5) melakukan refleksi terhadap strategi pengembangan pengetahuan yang didapat. 


\section{SIMPULAN}

Berdasarkan hasil pelaksanaan tindakan pada siklus I dan siklus II, dapat disimpulkan bahwa model pembelajaran CTL dapat meningkatkan hasil belajar pelajaran Mtk kelas V SD 104/IX Kedemangan. Melalui model pembelajaran CTL dapat menciptakan keaktifan pada siswa, siswa tampak memiliki ambisi yang tinggi, serta mempunyai kegigihan yang kuat menemukan pemecahan masalah atas keraguan terkait materi pelajaran, selanjutnya berdasarkan simpulan sebagaimana dikemukakan tersebut di atas ada beberapa saran yang dapat peneliti sampaikan yaitu:

1. Dalam kegiatan pembelajaran mtk, model pembelajaran CTL merupakan alternatif solusi bagi guru dan praktisi lainnya dalam meningkatkan hasil belajar siswa;

2. Model pembelajaran CTL dapat dijadikan referensi bagi guru bidang studi lainnya untuk melakukan hal yang sama melalui penelitian lanjutan, dengan melakukan perbandingan atas hasil temuan penelitian ini.

3. Model pembelajaran CTL dapat menjadi masukan bagi sekolah untuk meningkatkan kualitas mutu proses dan mutu hasil pembelajaran sehingga berdampak pada kualitas mutu sekolah secara keseluruhan.

\section{DAFTAR PUSTAKA}

Aqib, Z. 2017. Model-model, Media, dan strategi Pembelajaran Kontekstual (Inovatif) (VII ed.). Bandung: Yrama Widya.

Arikunto, S. 2006. Prosedur Penelitian: Suatu Pendekatan Praktik. Jakarta: Bumi Aksara.
Djaali. 2015. Psikologi Pendidikan (9 ed.). Jakarta: Bumi Aksara.

Hamdi, M. 2016. Teori Kepribadian Sebuah Pengantar (1 ed.). Bandung: Alfabeta.

Leonard, A. S. 2017. Pengaruh Model Pembelajaran Contextual Teaching And Learning (CTL) Terhadap Hasil Belajar Matematika Siswa. Prosiding Diskusi Panel Nasional Pendidikan matematika Fakultas Teknik Universitas Indraprasta PGRI.

Nasution. 2013. Berbagai Pendekatan dalam Proses Belajar \& Mengajar (16 ed.). Jakarta: PT Bumi Aksara.

Rahmawati, T. 2018. Penerapan Model Pembelajaran CTL untuk Meningkatkan Hasil Belajar Siswa Sekolah dasar pada Mata Pelajaran IPA. Jurnal Ilmiah Pendidikan dan Pembelajaran, 2 (1).

Sardiman. 2014. Interaksi \& Motivasi Belajar Mengajar (22 ed.). Jakarta: Rajawali Pers.

Setiono, K. 2009. Psikologi Perkembangan Kajian Teori Piaget, Selman, Kohlberg, dan Aplikasi Riset (2 ed.). Bandung: Widya Padjadjaran.

Sudjana. 2011. Hasil Belajar. Jakarta: Rineka Cipta.

Susanto, A. 2016. Teori Belajar \& Pembelajaran di Sekolah Dasar (4 ed.). Jakarta: PrenadaMedia Group.

Taniredja, T., Faridli, E. M., \& Harmianto, S. 2017. Model-model Pembelajaran Inovatif dan Efektif (7 ed.). Bandung: Alfabeta. 